\title{
Tinjauan Hukum Hak Waris Anak Diluar Nikah Berdasarkan Undang-Undang Nomor 1 Tahun 1974 Tentang Perkawinan (Studi Di Pengadilan Agama Pasarwajo)
}

\author{
Amrun Kahar \\ Fakultas Hukum Universitas Muhammadiyah Buton \\ Dosen Hukum Perdata
}

\begin{abstract}
The presence of a child outside of marriage/marriage will be a matter of sufficient concern for women who give birth to or for local people. This research will be conducted on Religious Pasarwajo Court, is based on the consideration that the data and information necessary and relevant to the issues in the research in, can be poroleh easily. The research results showed that the inheritance of the child outside of marriage based on law No. 1 year 1974 about marriage is a whole child outside mating born outside the marriage provision provision or requirement contained in article 2 paragraph (1) and paragraph (2) of law number 1 Year 1974 about marriage. Berdasrkan research results beyond the kawini children of the author, who is not at all in a marriage that is valid not included in the terms of mutual recognition of inherited, except by a man that it was his son who followed by the existence of DNA evidence and a blood test based on the decision of the constitutional Number Mahkama. 46/PUU-VIII/2010.
\end{abstract}

Keywords: Inheritance, Children outside of marriage, marriage.

\section{A. PENDAHULUAN}

Perkawinan merupakan peristiwa penting dalam kehidupan manusia yang menimbulkan akibat hukum baik hubungan antra pihak yang melangsungkan perkawinan itu sendiri, maupun dengan pihak lain yang mempunyai kepentingan tertentu. Apabila dari perkawinan itu di lahirkan anak, maka timbullah hubungan hokum antara anak dengan orang tuanya. Sebagai warga Negara anak berhak tunbuh berkembang sesuai dengan kodratnya sebagai makhluk tuhan. 
Anak sebagai hasil dari suatu perkawinan merupakan bagian yang sangat penting kedudukannya dalam suatu keluarga. Anak sebagai amanah Allah SWT, maka orang tua mempunyai tanggung jawab untuk mengasuh, mendidik, dan memenuhi keperluan sampai dewasa. Berdasarkan pasal 45dan 46 Undang-undang Nomor 1 Tahun 1974 tentang perkawinan, hubungan hokum antara orang tua dan anak menimbulkan hak dan kewajiban antara keduannya. Dalam pasal 45 Undang-undang Nomor 1 Tahun 1974 tentang perkawinan bahwa orang tua wajib memelihara dan mendidik anak-anak mereka sebaikbaiknya sampai anak itu kawin atau berdiri sendiri. Bahwa kewajiban itu berlaku terus meski perkawinan antara kedua orang tua putus. Sebaliknya anak mempunyai kewajiban terhadap orang tuanya yang di atur dalam pasal 46, yaitu anak wajib menghormati orang tua dan menaatu kehendak mereka yang baik, dan jika anak telah dewasa ia wajib memelihara menurut kemampuannya. Anak juga merupakan ahli waris yang berhak menerima warisan. Baik anak laki-laki maupun anak perempuan adalah ahli waris dari orangtuannya, bahkan ia adalah ahli waris yang paling dekat dengan pewaris.

Anak di golongkan menjadi 2 (dua) yaitu anak sah dan anak diluar nikah/kawin. Pasal 42 Undang-undang Nomor 1 Tahun 1974 tentang perkawinan, Menyatakan bahwa anak sah adalah anak yang di lahirkan dalam atau sebagai akibat perkawinan yang sah dan pasal 43 ayat (1) Undang-undang Nomor 1 Tahun 1974 tentang perkawinan menegaskan bahwa anak di luar kawin hanya mempunyai hubungan perdata dengan ibunya dan keluarga ibunya. Anak yang lahir dalam atau sebagai akibat perkawinan yang sah dan hasil pembuatan suami istri yang sah di luar Rahim dan di lahikan oleh istri tersebut merupakan anak yang sah sesuai pasal 99 kompilasi hukum islam. 
Kedudukan dan status anak dapat di lihat dari sah atau tidaknya suatu perkawinan yang langsungkan oleh kedua orang tuanya. Dalam hokum nasional di jelaskan bahwa suatu perkawinan yang sah apabila dicatatkan di lembaga atau instansi yang berwewenang mencatatkan nikah. Sedangkan dalam hokum islam, suatu perkawinan yang sah apabila sudah memenuhi syarat dan rukun nikah.

Pandangan hukum islam, anak yang di lahirkan di luar perkawinan yang sah namun tidak tercatat dalam kantor urusan agama (KUA) namun di kantor catatan sipil merupakan anak sah, karena dalam pandangan hokum islam sekalipun perkawinan itu di sebut Nikah sirri tetap perkawinan itu tidak sah, karena sudah memenuhi syarat dan rukun nikah.

Anak yang di lahirkan "di luar perkawinan”, perkawinannya hanya memenuhi pasal 2 Ayat (1) Undang-undang Nomor 1 Tahun 1974 bahwa "perkawinan adalah sah, apabila dilakukan menurut hokum masing-masing agamanya dan kepercayaanya itu", dan tidak memenuhi pasal 2 Ayat (2) Undang- undang Nomor 1 Tahun 1974 bahwa "Tiap-tiap perkawinan di catat menurut peraturan perundang-undangan yang berlaku.

Perkawinan yang hanya dilakukan secara agama atau biasanya di sebuh nikah siri tampa adanya percatatan di Kantor Urusan Agama (KUA). Sedangkan penjelasan pasal 2 Ayat (2) Undang-undang Nomor 1 Tahun 1974 Tentang Perkainan. Perkawinan yang sah adalah perkawinan yang di catatkan. Perkawinan yang tidak di catatkan adalah perkawinan yang tidak sah, dan anak yang di lahirkan atas perkawinan tersebut adalah anak tidak sah atau anak di luar kawin. Akibat yang timbul dari itu sesuai pasal 43 ayat (1) bahwa anak diluar perkawinan hanya mempunyai hubungan perdata dengan ibunya atau keluarga ibunya. 
Kehadiran anak diluar nikah/perkawinan akan menjadi masalah yang cukup memprihatinkan bagi wanita yang melahirkan ataupun bagi masyarakat setempat. Dimana dengan anak yang dilahirkan dari luar perkawinan itu akan banyak menimbulkan pertentangan-pertentangan dianatara keluarga maupun didalam masyarakat mengenai kedudukan hak dan kewajiban anak tersebut.

Status sebagai anak yang di lahirkan diluar nikah/perkawinan merupakan suatu masalah bagi anak di luar nikah tersebut, karena mereka tidak mempunyai hak-hak dan kedudukan sebagai anak pada umumnya seperti anak yang sah karena secara hokum mereka hanya memiliki hubungan perdata dengan ibunya dan keluarga ibunya. Anak di luar nikah tidak memperoleh hak yang memjadi keqwajiban ayahnya, karena ketidak absahanya pada anak di luar nikah tersebut.

Permasalahan yang lain kemungkinan terjadi apabila sang ayah dari anak diluar nikah/kawin tersebut meninggal dunia dan meninggalkan anak tersebut dengan ibunya apakah anak tersebut dapat mendapatkan hak-haknya sebagai anak dari ayah boiligisnya. Hak-hak dari seorang anak dalam hal ini ialah hak wasis mewarisi antara pewaris yaitu si ayah dan si ahli waris ialah anak. Karena bagaimanapun si ayah tersebut berhubungan darah dengan si anak dan tetap menjadi ayah biologis si anak. Apakah anak tersebut mendapatkan haknya sebagai anak dari ayah biologisnya atau tidak berhak sama sekali seperti yang tertulis dalam perundang-undangan.

\section{B. METODE PENELITIAN}

Penelitian ini akan dilakukan pada Pengadilan Agama Pasarwajo, dengan di dasarkan pada pertimbangan bahwa data dan informasi yang dibutuhkan dan relevan 
dengan permasalahan dalam penelitian in, dapat di poroleh dengan mudah. Sifat penelitian yang digunakan penulis ialah penelitian Yuridis normatif. Penelitian yuridis normatif yaitu dengan mengkaji peraturan perundang-undangan, teori-teori hukum dan yurispudensi yang berhubungan dengan permasalahan yang dibahas.

\section{HASIL DAN PEMBAHASAN}

1. Hak Waris Anak Diluar Nikah Sebagai Ahli Waris Berdasarkan Undang-undang Nomor 1 Tahun 1974 Tentang Perkawinan Di Pengadilan Agama PasarWajo

Permasalahan anak diluar nikah tidak hanya sampai pada pengertian dan makna anak luar nikah itu, karena dalam pasal 43 ayat (1) menyebutkan bahwa anak yang di lahirkan diluar perkawinan hanya mempunyai hubungan perdata dengan ibunya dan keluarga ibunya. Sedangkan pada putusan Mahkama Konstitusi No. 46/PUU-VIII/2010 dikeluarkan pada tanggal 17 februari 2012, berdasarkan permohonan uji materi Undangundang Nomor 1 Tahun 1974 Tentang perkawinan memutus tentang hak keperdataaan anak luar nikah dengan sang ayah biologisnya, permasalahan selanjutnya bagaimana hak keperdataan yang didapat dari seorang anak luar perkawinan dari sang ayah.

Mahfud MD (Media Indonesia Express Kamis, 29/03/2012) menyatakan, hubungan perdata yang di berikan pada anak diluar perkawinan tidak berbentuk nasab, waris, dan wali nika. Hak yang dapat dituntut anak di luar nikah/perkawinan yang tidak di atur fiqih antara lain berupa hak menuntut pembiayaan pendidikan, atau hak menuntut ganti rugi karena perbuatan melawan hUkum yang merugikan orang lain. Intinya adalah hak-hak perdata selain hak nasab, hak waris, wali nikah, atau hak perdata apapun yang tidak terkait dengan prinsip-prinsip munakahat sesuai fiqih. 
Menurut Akil Mochtar (http:/irmadevita.com, diunduh 6 oktober 2016) anak yang dilahirkan dalam perkawinan sirri, seharusnya termasuk dalam anak sah karena dengan adanya putusan Mahkama Konstitusi telah di akui bahwa perkawinan yang di lakukan sesuai dengan syarat-syarat yang di tetapkan oleh agama masing-masing pasangan calon mempelai adalah perkawinan yang sah meskipun perkawinan itu tidak di catat dalam catatan administrasi Negara.

Akan tetapi, dalam prakteknya pada saat melakukan penelitian dari 5 (lima) anak yang dilahirkan dalam perkawinan sirri justru di golongkan dalam anak luar kawin sehingga si anak tidak memperoleh hak-hak keperdataan sebagai mana mestinya. Anak dalam akta kelahiran tidak di camtumkan nama bapaknya, singga muncul sigma negatif dalam masyarakat. Di tambah lagi berkembangnya praktek dalam masyarakat bahwa kawin sirri merupakan praktek poligami terselubung. Pihak laki-laki terutama sering menyangkal adanya perkawinan tersebut sehingga hak-hak anak yang lahir dalam perkawinan tersebut tidak di penuhi.

Menurut sumber yang tidak mau di sebutkan namanya (Wawancara tanggal 5 Oktober 2016) bahwa sebenarnya, harta warisan tidak menjadi persoalan, tetapi yang menjadi persoalan adalah pengakuan bahwa anak itu adalah anak ayahnya. Lebih lanjut sumber mengatakan bahwa untuk mengurus akta kelahiran saja saat ini harus ada buku nikah kedua orang tua anak.

Irma Devita. (http:/irmadevita.com/2012/perlindungan-anak-luar-kawin-pascaputusanmahkama-konstitusi, diunduh 29 november2016) menjelaskan bahwa dalam kompilasi hukum islam asal usul anak hanya dapat di buktikan dengan akta kelahiran. Akta 
tetap pengadilan Agama di berikan kewenangan untuk mengeluarkan ketetapan (isbat) bila tidak ada akta kelahiran dari anak tersebut. Pengadilan memeriksa asal-usul anak tersebut dengan mendasarkan alat-alat bukti yang sah, seperti keterangan saksi-saksi, tes DNA, pengakuan ayah (istilhaq) sumpah ibu dan alat-alat bukti lainya yang sah menurut hukum.

Menurut Umar Shihab (Majalah konstitusi edisi Februari 2012 hal.17) bahwa, putusan Mahkama Konstitusi No. 46/PUUVIII/2010 menjelaskan dasar hokum bagi hakim dalam memutus. Kalau tes DNAnya menyatakan itu ayahnya, maka sang ayah harus bertanggung jawab, anak yang lahir diluar nikah ada dua kemungkinan anak diakui oleh ayahnya atau tidak. Kalau ayahnya mengakui maka tidak ada masalah, kalau tidak mengakui maka dibuktikan ke pengadilan, selanjutnya pembuktian di pengadilan yang akan memutuskan nasib anak apakah benar anaknya atau tidak. Yaitu dengan menggunakan sarana ilmu pengetahuan dan teknologi yang bersedia dan di akui secara hukum. Apun untuk perkawinan sirrim, menurut Umar, tidak ada masalah dalam islam. Sebab Nikah sirri di akui secara sah dalam syariah islam. Brdasarkan putusan Mahkama Konstitusi No. 46/PUUVIII/2010 anak yang lahir diluar nikah hak-hak wasinya dari ayahnya, seandainya di belakang hari laki-laki mengelak tidak mengakui perkawinan tersebut maka tinggal di buktikan di pengadilan. Umar juga mengatakan "Bedanya anak yang lahir di luar perkawinan dia tidak mendapat hak waris, tetapi kalau lahir dari nikah sirri maka secara agama tetap dapat hak waris, nasab, nafkah, biaya pendidikan dan sebagainya. 
Menurut H.M. Nurul Irfan (http:/ news.detik.com, diunduh tanggal 2 oktober 2016), Putusan Mahkama Konstitusi No. 46/PUUVIII/2010 menjadilan anak diluar kawin sebagai pihak yang memiliki kedudukan hukum dalam perkara kewarisan di pengadilan dan berhak memperoleh harta warisan ayah biologisnya dengan keharusan mampu membuktikan adanya hubungan darah berdasarkan ilmu pengetahuan dan teknologi dan/atau alat bukti lain menurut hukum.

Sedangkan Hj. Nurbaya, Hakim Pengadilan Agama Pasarwajo (Wawancara tanggal 5 Oktober 2016 ) berpendapat putusan Mahkama Konstitusi No. 46/PUUVIII/2010 tersebut memang mengarah pada pembagian harta ayah kepada anak di luar nikah. Tetapi, pembagian harta tidak bias di implementasikan sebagai warisan menurut konsep dasar hukum Islam yaitu anak laki-laki mendapat harta dua kali lipat ketimbanganak perempuan. Hal tersebut dikarenakan warisan menurut konsep dasar Hukum Islam memiliki syarat seperti adanya nasab atau hubungan sah menurut perkawinan. Nasan adalah keturunan sedarah atau hubungan-hubungan kekerabatan di dalam Islam melalui perkawinan yang sah atau melalui pengakuan seorang laki-laki bahwa itu anaknya yang di akuti dengan adanya bukti-bukti DNA dan tes darah. Selanjutnya Hj. Nurbaya mengatakan " kalau mau disingkronisasikan dengan konsep dasar hukum islam jangan di beri nama waris, kalau waris syaratnya harus ada hubungan kekerabatan yang sah. Jadi silakan memperoleh hanya tetapi bukan nama waris, misalnya hibah, sedekah, dan lain-lain.

Sehubungan dengan pembagian hak waris anak diluar nikah pada Pengadilan Agama Pasarwajo belum pernah terjadi atau belum ada kasus. Untuk lebih jelasnya hal tersebut di dapat dilihat pada table sebagai berikut: 
Tabel I:

Data Hak Anak Diluar Nikah

\begin{tabular}{|l|l|c|l|}
\hline No. & Kasus & Jumlah Kasus & Keterangan \\
\hline 1. & Waris & 0 & $\begin{array}{l}\text { Ada Hubungan } \\
\text { Kekerabatan }\end{array}$ \\
\hline 2. & Hibah & 0 & Tidak Ada Hubungan \\
Kekerabatan \\
\hline 3. & Sedekah & 0 & Tidak Ada Hubungan \\
& & & Kekerabatan \\
\hline
\end{tabular}

Sumber Data: Pengadilan Agama Pasarwajo, Tahun 2016

A Mukti Anto, (http:/badilag.net/data/artikel/diskudi/\%20hukum. Diunduh 6 Oktober 2016) menyebutkan hokum perdata yang timbul akibat dari adanya hubungan dara ini meliputi hubungan hokum, hak dan kewajiban antara anak dengan ayah dan ibunya yang dapat berupa: (1) hubungan nasab, (2) hubungan mahram, (3) hubungan hak dan kewajiban, (4) hubungan kewarisan (saling mewarisi) yang merupakan pelanjutan dari hubungan hak dan kewajiban karean nasab ketika mereka sama masih hidup dan (5) hubungan wali nikah bagi anak perempuan.

Ahmad Rofiq (2003:380) menyebutkan salah satu sabda Nabi dalam Hadis riwayat Muttafaq “alaiha yang di riwayatkan oleh bukhari dan muslim:' Nabi SAW bersabda: beriaklah bagian-bagian tertentu kepada orang orang yang berhak". Maka demikian, hubungan waris adalah suatu hokum yang mengatur tentang hak dan kewajiban serta tata cara pembagian harta peninggalan dari seorang yang sudah meninggal(pewaris) kepda 
keluarga dan kerabat-kerabatnya yang di tinggalkan (ahli waris). Saling mewarisi terjadi antara pewaris dengan ahli warisnya. Proses saling mewarisi tidak sedemikian rupa terjadi dengan sendirinya, ada beberapa sebab-sebab terjadinya saling waris ialah:

a) Al-Qarabah (pertalian darah)

Sebab saling mewarisi berasal dari hubungan darah, dimana semua ahli waris yang mempunyai hubungan darah mendapatkan bagiannya sesuai dengan dekat jauhnya kekerabatannya. Baik itu laki-laki, bahkan bayi yang masih dalam kandungan memiliki hak yang sama dengan orang dewasa.

b) Al-Musahrah (hubungan perkawinan)

Sebab saling mewarisi Al-Musahrah berasal dari perkawinan yang sah antara seorang laki-laki dan perempuan, baik menurut hokum agama dan kepercayaan maupun hokum Negara yang memyebabkan adanya hubungan saling mewarisi.

c) Al-Wala (memerdekakan hamba sahaya)

Al-Wala adalah hubungan kewarisan karena seorang memerdekakan hamba sahaya, atau melalui perjanjian tolong menolong. Laki-laki disebut ma'tiq dan perempuan disebut mu'tiqah. Bagiannya 1/6 dari harta waris pewaris.

\section{Pandangan Hukum Islam Terhadap Anak Diluar Nikah Sebagai Ahli Waris Berdasarkan Undang-Undang Nomor 1 Tahun 1974 Tentang Perkawinan}

Undang-undang Nomor 1 Tahun 1976 Tentang Perkawinan, Pasal 43 ayat (1) dan ayat (2) hanya menyebabkan: (1) Anak yang dilahirkan di luar perkawinan hanya mempunyai hubungan perdata dengan ibunya dan keluarga ibunya. (2) Kedudukan anak tersebut ayat (1) diatas selanjutnya akan diatur dalam peraturan pemerintah. 
Anak yang lahir di luar perkawinan hanya mempunyai hubungan nasab dengan ibunya dan keluarga ibunya, hal ini sesuai dengan pasal 100 kompilasi hokum islam. Sehubungan dengan hal tersebut kemudian putusan mahkama konstitusi No. 46/PUUVIII/2010 dikeluarkan pada tanggal 17 Februai 2012 berdasarkan permohonan uji materi pasal 2 ayat (2) dan pasal 43 ayat (1) Undang-Undang Nomor 1 Tahun 1974 Tentang Perkawinan.

Permohonan mempertanyakan konstitusional pasal 2 ayat (2) dan pasal 43 ayat (1) Undang-undang Nomor 1 Tahun 1974 Tentang Pekawinan. Akibat kedua pasal tersebut, pemohon merasa hak konstitusionalnya dirugikan karena tidak bisa mendapatkan pengesahan status hukum bagi anak pemohon yang merupakan hasil hubungan dari perkawinan sirri.

Amar putusan Mahkama Konstitusi No. 46/PUUVIII/2010 mengabulkan permohonan uji materi pemohon dengan menyatakan: Pasal 43 ayat (1) Undang-undang Nomor 1 Tahun 1974 menyebutkan " Anak yang dilahirkan di luar perkawinan mempunyai hubungan perdata dengan ibunya dan keluarga ibunya serta dengan laki-laki sebagai ayahnya yang dapat dibuktikan berdasarkan ilmu pengetahuan dan teknologi dan/atau alat bukti lain menurut hukum mempunyai hubungan darah, termasuk hubungan perdata dengan kuluarga ayahnya.

Dalam putusan Mahkama Konstitusi berpendapat bahwa "Secara alamiah, tidak mungkin seorang perempuan hamil tanpa adanya pertemuan antara ovum dan spermatozoa baik melalu hubungan seksual (coitus) maupun melalui cara lainberdasarkan perkembangan teknologi yang menyebabkan terjadinya pertumbuhan. Oleh, karena itu 
tidak tepat dan tidak adil manakala hukum menetapkan bahwa anak yang lahir dari suatu kehamilan karena hubungan seksual diluar perkawinan hanya memiliki hubungan dengan perempuan tersebut sebagai ibunya. Adalah tidak tepat dan tidak adil pula jika hukum membebaskan laki-laki yang melakukan hubungan seksual yang menyebabkan terjadinya kehamilan dan kelahiran anak tersebut dari tanggung jawabnya sebagai seorang bapak dan bersamaan dengan itu hukum meniadakan hak-hak anak terhadap lelaki tersebut sebagai bapaknya. Lebih-lebih manakala berdasarkan perkembangan teknologi yang ada memungkinkan dapat dibuktikan bahwa seorang anak itu merupakan anak dari laki-laki tertentu.

Putusan Mahkama Konstitusi No.46/PUU-VIII/2010 mengundang kontroversi, ada beberapa pihak yang menganggap putusan mahkama konstitusi itu memberikan jaminan dan perlingdungan terhadap anak di luar perkawinan resmi. Padahal sebelumnya, seuai pasal 43 (1) Undang-Undang No.1 Tahun 1974 "Anak diluar kawin hanya punya hubungan dengan ibu dan keluarga sang ibu". Reaksi yang paling terlihat dari MUI. Sebab keputusan itu bertentangan dengan ajaran Islam. Jika dibiarkan akan menimbulkan kegelisahan, kerisauan, bahkan kegoncangan bagi umat Islam.

Drs. Imam Tabroni (Lensa Kasus Edisi Mei 2012, Hal.17) berpendapat bahwa “ Putusan Mahkama Tersebut terindikasi memutar balikan ajaran Islam dan lebih gawat lagi mengubah syariat agama. Padahal dalam hukum islam telah secara tegas dijelaskan tentang ketiadaan hubungan keperdataan anak hasil perzinahan dengan lelaki yang menyebabkan kelahirannya. 
Hj. Nurbaya, Hakim Pengadilan Agama Pasarwajo (Wawancara Tanggal 5 Oktober 2016) menanggapi tentang anak diluar kawin sesuai dengan putusan Mahkama Konstitusi bahwa "anak yang lahir di luar kawin sesuai dengan putusan Mahkama Konstitusi itu ada tiga macam, yang pertama ialah anak diluar kawin resmi atau biasa di sebut kawin sirri, yang kedua ialah anak yang diluar kawin yang kemudian ketika ibunya masih hamilkemudian di kawini oleh ayah sianak biasa di sebut kawin wanita hamil dan yang terkhir ialah anak diluar kawin yang tidak pernah sama sekali ada perkawinan atau biasa di sebut anak zinah. Apabila kategori pertama anak diluar kawin itu merupakan anak bapaknya, karena dalam hukum Islam kawin sirri itu merupakan kawin yang sah sehingga sama dengan anak sah, kemudian yang kedua anak yang lahir ketika ibunya hamil dikawini oleh suami yang merupakan bapak biologis anaknya juga merupakan anak yang sah, dan yang ketiga anak luar kawin yang tidak pernah dikawini tidak bisa disebut anak sah dan merupakan anak luar kawin.

Selanjutnya Hj. Nurbaya, Mengemukakan bahwa" apabila putusan mahkama konstitusi mengakibatkan semua anak diluar kawin mempunyai hubungan keperdataan anak luar kawin dengan warisan yang dalam hal ini nasab tentu tidak bisa. Karena yang sebelumnya saya jelaskan bahwa anak diluar kawin ada tiga macam dan yang ketigatiganya boleh mendapatkan hubungan keperdataan namun untuk hubungan nasab hanya anak luar kawin dalam perkawinan sirri dan anak diluar kawin yang kemudian ibunya dikawini oleh bapak biologisnya si anak yang mendapatkannya.

Chatib Rasyid Ketua Pengadilan Tinggi Semarang (makalah dalam seminar status anak diluar kawin dan hak keperdataan lainnya, pada tanggal 10 april 2012, di IAIN 
Walisongo Semarang) berpendapat bahwa dari putusan mahkama konstitusi no. 46/PUUVIII/2010 ada beberapa hal yang pantut menjadi catatan. Pertama, persoalan status anak yang lahir di luat perkawinan itu bermuara pada masalah perkawinan yang tidak tercatat. Kedua, pengembangan analisis selanjutnya adalah seputar anak yang lahir diluar perkawinan, dan anak yang sah dalam perspektif bahasa. Ketiga, menyangkut pengadilan agama.

Selanjutnya Chatib Rasyid mengemukakan bahwa "kenyataan yang ada di masyarakat luas, anak Indonesia terdapat tiga macam status kelahirannya, yaitu anak yang lahir dalam atau sebagai akibat perkawinan yang sah; anak yang lahir di perkawinan; anak yang lahir tanpa perkawinan (anak zinah)”. Pasal 43 ayat (1) Undang-Undang no.1 Tahun 1974 tentang perkawinan, itu tidak berdiri sendiri, sangat berkaitan dengan adanya perkawinan sebagai mana di atur oleh pasal 2 Undang-Undang no.1 Tahun 1974. Di sebut luar perkawianan, karna perkawinan itu dilakukan di luar prosedur pada pasal 2 ayat (2) tidak bisa "luar perkawian "itu di artikan sebagai perzinaan, karna perbuatan zinah itu di lakukan sama sekali tanpa ada perkawinan, beda sekali antara luar perkawinan dengan tanpa perkawinan.

H. Muhtar, Kepala Kantor Kemenag. Kabupaten Buton (wawancara tanggal 10 Oktober 2016) mengatakan bahwa "anak yang lahir dari perkawinan sirrihdi golongkan pada anak luar kawin. Dengan di akuinya perkawinan yang sesuai dengan ajaran agama masing-masing mempelai namun tidak di catatkan sebagai suatu perkawinan yang sah maka seharusnya anaka yang lahir dari perkawinan tersebut termasuk sebagai anak sah. Namun kenyataan, anak itu di golongkan sebagai anak luar kawin ujur. 
Dari putusan mahkama konstitusi no. 46/PUU/VIII/2010 menurut Chatib Rasyid (Http:/Badiag. Net/data/artikel, majalah 2 makna, di unduh tanggal 2 November 2016) dapat di simpulkan hal hal sebagai berikur: (1) yang di maksud dengan anak yang lahir di luar perkawinan adalah anak yang lahir dari perkawinan menurut agama, tetapi tidak tercatat menurut peraturan perundang-undangan yang berlaku, dalam arti kata sah secara materil tetapi tidak sah secara formil. Tidak termasuk anak yang lahir tampa perkawinan (anak zinah), karena anak zinah sama sekali tidak tersentuh dengan perkawinan. (2) Untuk melegalkan "anak yang lahir diluar perkawinan" secara hukum adalah dengan terlebih dahulu dengan melakukan pengesahan (isbat kawin) di pengadilan dan di lanjutkan dengan pengesahan anak di pengadilan yang sama. Dengan adanya pengesahan anak dari pengadilan maka anak yang lahir dari luar perkawinan sudah seutuhnya sama dengan anak yang lahir dalam atau akibat perkawinan yang sah. (3) Anak yang lahir tampa perkawinan (anak hasil zinah) tidak dapat di legalkan secara hukum, karena di samping tidak ada lembaga pengesahan zinah juga perbuatan zinah adalah merupakan perbuatan yang melanggar hukum yang tidak layak mendapatkan legalitasi hukum.

Menurut Hj. Nurbaya (Wawancara tanggal 5 Oktober 2016) bahwa "hokum Islam dengan putusan mahkama konstitusi itu berbeda, artinya dua hal yang tidak bisa di hubungkan, apbila putusan mahkama konstitusi itu menjadi pedoman bagi peraturan perundang-undangan yang di bawahnya dan diterapkan oleh pengadilan Agama maupun Pengadilan Negeri. Jadi sebenarnya ada atau tidaknya Putusan Mahkama Konstitusi terhadap anak diluar kawin tidak berpengaruh dalam Hukum Islam. Karena dalam hokum Islam anak diluar kawin didalam perkawinan yang sah walaupun tidak dicatat kedudukan 
anaknya sama dengan anak sah. Kecuali anak luar kawin zinah, anak zinah tidak bisa berubah menjadi anak apapun.

\section{PENUTUP}

Berdasarkan hasil penelitian mengenai hak waris Anak Luar Nikah Berdasarkan Undang-Undang No. 1 Tahun 1974 tentang perkawinan, maka penulis menyimpulkan sebagai berikut:

Hak Waris Anak Diluar Nikah sebagai Ahli waris berdasarkan Undang-Undang No. 1 Tahun 1974 tentang perkawinan,DIPENGADILAN Agama Pasar Wajo.Anak Luar Kawin merupakan seluruh anak luar kawin yang lahir diluar perkawinan yang ketentuan yang ketentuan ataupun syaratnya tertuang dalam pasal 2 Ayat (1) dan Ayat (2) Undang-undang Nomor 1 Tahun 1974 tentang perkawinan.

Anak luar kawin terbagi dalam 3 golongan yaitu: (a) Anak luar nikah/kawin dalam perkawinan yang sah menurut agama Islam maupun tidak dicatatkan atau bisa disebut dengan kawin sirri; Anak luar nikah/kawin yang dimana ibu dari anak tersebut hamil kemudian dikawini oleh bapaknya si anak atau sering disebut perkawinan wanita hamil;(c) Anak luar kawin yang sama sekalitidak dalam perkawinan yang sah atau sering di sebut anak zinah.

Berdasrkan hasil penelitian penulis, anak luar kawini yang sama sekali tidak dalam suatu perkawinan yang sah tidak termasuk dalam hal saling mewarisi, kecuali melalui pengakuan seorang laki-laki bahwa itu anaknya yang diikuti dengan adanya bukti-bukti DNA dan tes darah berdasarkan Keputusan Mahkama Konstitusi Nomor.46/PUUVIII/2010. 
Pandangan Hukum Islam terhadap Anak Diluar Nikah/Kawis sebagai ahli waris berdasarkan Undang-Undang yang berlaku Nomor 1 Tahun 1974 Tentang Perkawinan. Untuk bagian waris anak luar kawin dalam perkawinan sirri sama dengan bagian dalam perkawinan yang sah.

Untuk manak perempuan apabila sendiri atau hanya seorang maka akan mendapatkan bagian $1 / 2$ dan apabila anak perempuan tersebut lebih dari satu orang maka akan mendapatkan 2/3 bagian. Satu anak perenpuan jika ia mewarisi bersama 1 atau lebih cucu perempuan, maka perempuan akan mendapatkan $1 / 2$ bagian dan satu atau lebih cucu perempuan mendapatkan $1 / 6$ bagian.

\section{DAFTAR PUSTAKA}

Abdul Manah, 2008. Aneka Masalah Hukum Perdata Islam Di Indonesia Jakarta: Prenada Media

Ahmad Rofiq, 2003. Hukum Islam Di Indonesia. Jakarta: PT. Raja Grafindo Persada.

Amir Syarifuddin, 2002. Hukum Perkawinan Islam Di Indonesia: Antara Fiqrh Munakat Dan Undang-Undang Perkawinan. Jakarta: Prenada Media Grup.

Baidhowi. 2010. Buku Ajar Hukum Kekeluargaan dan Waris Islam. Semarang: Unnes Beni Ahmad Saebani, 2008. Metode Penelitian Hukum. Bandung Pustaka Setia. Hasbi Ash-Shidieqy, 1983. Hukum Waris Dalam Syariat Islam. Jakarta: Bulan Bintang. Hilam Hadikusuma. 1990. Hukum Perkawinan Adat. Bandung. Citra Aditnya Bakti.

Hilam Hadikusuma.1990. Hukum Perkawinan Indonesia Menutut Perundangan, Hukum Adat, Hukum Agama, Bandung: Mandar Mandur.

Ibrahim Johni. 2006. Teori dan Metode Penelitian Hukum Normatif, Malang: Bayu media Publising.

Jonathan Sarwono, 2006, Metode Penelitian Kuantitatif dan Kualitatif. Yogyakarta: Graha Ilmu. 
Komariah. 2005. Hukum Perdata. Malang: UMM Malang.

Lexy Moleang, 2007. Metode Penelitian Kualitatif. Bandung: Remaja Rosada Karya.

Mohammad Daud Ali. 2004. Hukum Islam Pengantar Ilmu Hukum Dan Tata Hukum Islam di Indonesia. Jakarta: PT. Raja Grafindo Persada.

Mohammad Idris Ramulyo, 2000. Perbandingan Hukum Kewarisan Islam Dengan Kewarisan Menurut KUHPER (BW). Sinar Grafika, Jakarta.

Muslan Abdurrahyman, 2009, Sosiologi dan Metode Penelitian Hukum Cetakan Pertama. Malang: UMM Press

R. Wirjono Pradjodikoro, 1974, Hukum Perkawinan Di Indonesia. Sumur Bandung, Bandung.

H.M. Idris Ramulyo. 2004. Perbandingan Hukum Kewarisan Islam. Sinar Grafika. Jakarta.

H. R. Otje Salman dan Mustofa Haffas, 2006. Hukum Waris Islam. Bandung: PT. Refika Aditama. 